\title{
Degradation of emerald green: scientific studies on multi-polychrome Vairocana Statue in Dazu Rock Carvings, Chongqing, China
}

\author{
Zhimin Li', Lele Wang ${ }^{2}$, Huili Chen ${ }^{3}$ and Qinglin Ma ${ }^{4,5^{*}}$
}

\begin{abstract}
The spontaneous degradation of pigments in painting may occur depending on environment, especially the surrounding condition of high humidity and soluble salts. Even some of these are well studied, more investigations are still in need for heritage science. Paint cross sections from Vairocana Statue in Dazu Rock Carvings, one of World Cultural Heritage, Chongqing, China are studied by optical microscopy (OM), Raman spectroscopy (Raman) and mapping, and scanning electron microscopy coupled with energy dispersive X-ray analysis (SEM-EDS). Ultramarine blue, emerald green, synthetic atacamite, vermilion, red lead, gold foil, orpiment, cerussite, gypsum and barite are identified as pigments. Moreover, lavendulan $\left(\mathrm{NaCaCu}_{5}\left(\mathrm{AsO}_{4}\right)_{4} \mathrm{Cl} \cdot 5 \mathrm{H}_{2} \mathrm{O}\right)$ and mimetite $\left(\mathrm{Pb}_{5}\left(\mathrm{AsO}_{4}\right)_{3} \mathrm{Cl}\right)$ are degradation products of emerald green $\left(\mathrm{Cu}\left(\mathrm{C}_{2} \mathrm{H}_{3} \mathrm{O}_{2}\right)_{2} \cdot 3 \mathrm{Cu}\left(\mathrm{AsO}_{2}\right)_{2}\right)$ and cerussite $\left(\mathrm{PbCO}_{3}\right)$ originally used as green pigment with mixture. These secondary products are formed via multistep progresses as degradation of emerald green and cerussite, oxidation of arsenite $\left(\left(\mathrm{AsO}_{2}\right)^{-}\right)$, migration of arsenate $\left(\left(\mathrm{AsO}_{4}\right)^{3-}\right)$ and precipitation reaction of these ions with other necessary ions from environmental conditions. Based on the pigment and paint layer stratigraphy analysis, the paintings of the statue have been executed at least four times and the most recent may be after 1850s. The formation of lavendulan give rise to a highlight for identification of green copper-arsenic containing pigments and characterization of degradation in complex conditions.
\end{abstract}

Keywords: Dazu Rock Carvings, Pigment, Degradation, Raman mapping, Emerald green, Lavendulan, Mimetite

\section{Introduction}

Degradation phenomena occur in the paintings where original pigments, binding media, ground layer and substrate to undergo chemical and physical transformations, leading to discolouration or deterioration of materials. These processes can be initiated by internal factors, for example the characteristics of pigments with organic binders and other materials, or by external factors, which suffer from environmental conditions (relative humidity, illumination, temperature, etc.), biological activity, pollution or human interventions, or several of these together

\footnotetext{
*Correspondence: qinglinma226@126.com

${ }^{4}$ International Joint Research Laboratory of Environmental and Social Archaeology, Shandong University, Qingdao 266237, Shandong, China Full list of author information is available at the end of the article
}

$[1,2]$. Degradation of pigments can be visually perceived as color changes or confirmed as structural modifications by employing modern analytical or micro-analytical methods.

Studies on degradation processes and products of pigments inside museum on oil paintings, manuscripts and in an outdoor environment on polychrome statue and wall paintings are well known and documented. Azurite $\left(2 \mathrm{CuCO}_{3} \cdot \mathrm{Cu}(\mathrm{OH})_{2}\right)$ and malachite $\left(\mathrm{CuCO}_{3} \cdot \mathrm{Cu}(\mathrm{OH})_{2}\right)$, as the best representatives of basic copper salts (carbonates, chlorides, sulphates, etc.), are widely used as mineral blue and green pigments. In the case of artifacts, the published data indicates the transformation of azurite and malachite into green basic $\mathrm{Cu}$ chlorides in the presence of chloride and humidity [3-5]. Arsenic-based pigments such as orpiment $\left(\mathrm{As}_{2} \mathrm{~S}_{3}\right)$ and realgar $\left(\mathrm{As}_{4} \mathrm{~S}_{4}\right)$ are highly
Springer Open

(c) The Author(s) 2020. This article is licensed under a Creative Commons Attribution 4.0 International License, which permits use, sharing adaptation, distribution and reproduction in any medium or format, as long as you give appropriate credit to the original author(s) and the source, provide a link to the Creative Commons licence, and indicate if changes were made. The images or other third party material in this article are included in the article's Creative Commons licence, unless indicated otherwise in a credit line to the material. If material is not included in the article's Creative Commons licence and your intended use is not permitted by statutory regulation or exceeds the permitted use, you will need to obtain permission directly from the copyright holder. To view a copy of this licence, visit http://creativeco mmons.org/licenses/by/4.0/. The Creative Commons Public Domain Dedication waiver (http://creativecommons.org/publicdomain/ zero/1.0/) applies to the data made available in this article, unless otherwise stated in a credit line to the data. 
appreciated in China for yellow and red to red-orange tones. Arsenic sulfide pigments are bound to shift color exposed to visible light and realgar undergoes photoinduced polymorphism and becomes friable, assuming hues from bright yellow pararealgar $\left(\mathrm{As}_{4} \mathrm{~S}_{4}\right)$ to colorless arsenolite $\left(\mathrm{As}_{2} \mathrm{O}_{3}\right)$ whereas the photo-oxidation of orpiment results in arsenolite [6-8]. Lead pigments e.g. lead white $\left(2 \mathrm{PbCO}_{3} \cdot \mathrm{Pb}(\mathrm{OH})_{2}\right)$, red lead $\left(\mathrm{Pb}_{3} \mathrm{O}_{4}\right)$ are employed owing to bright colors and high covering power in paintings. Lead pigments turn black caused by reaction with sulphur-containing compounds to black galena $(\mathrm{PbS})$ and oxidation to the black-brown plattnerite $\left(\mathrm{PbO}_{2}\right)[9,10]$. Vermillion ( $\mathrm{HgS})$ is extensively used as bright red pigment. It darkens attributed to the formation of a black compound, metacinnabar $(\beta-\mathrm{HgS})$ when exposed to light and $\mathrm{HgCl}_{2}$ when $\mathrm{Cl}^{-}$ions present in the pigments [11, 12].

A popular man-made brilliant green pigment, emerald green $\left(\mathrm{Cu}\left(\mathrm{C}_{2} \mathrm{H}_{3} \mathrm{O}_{2}\right)_{2} \cdot 3 \mathrm{Cu}\left(\mathrm{AsO}_{2}\right)_{2}\right)$, containing copper and arsenic is found to be unstable in paints. Emerald green darkens as it mixed with sulphur-containing compounds from the atmosphere to form brown copper sulfides $(\mathrm{CuS})$ [13]. Emerald green degrades in oil paintings rich with a relatively high concentration of monoacids, diacids and resin acids, forming copper soaps $\left(4 \mathrm{Cu}(\mathrm{FA})_{2}\right)$ $(\mathrm{FA}=$ fatty acids $)$ and arsenic trioxide $\left(\mathrm{As}_{2} \mathrm{O}_{3}\right)$, leading to transparent discolored brown layers [14]. Emerald green is also found to transform to mineral lammerite $\left(\mathrm{Cu}_{3}\left(\mathrm{AsO}_{4}\right)_{2}\right)$ in wall paintings as a result of the migration of arsenic [15]. Recently, rare lead arsenate mineral, mimetite $\left(\mathrm{Pb}_{5}\left(\mathrm{AsO}_{4}\right)_{3} \mathrm{Cl}\right)$, is shown to be degradation product of multistep alteration pathway of pigments orpiment and realgar and arsenate ions $\left(\left(\mathrm{AsO}_{4}\right)^{3-}\right)$ to precipitate with $\mathrm{Pb}^{2+}$ ions [16-18].

Lavendulan $\left(\mathrm{NaCaCu}_{5}\left(\mathrm{AsO}_{4}\right)_{4} \mathrm{Cl} \cdot 5 \mathrm{H}_{2} \mathrm{O}\right)$, an uncommon copper arsenate mineral, was originally described by Breithaupt in 1837 from Annaberg. It was first found by Vogel in 1853 at Joachimsthal, and then by Goldsmith in 1877 from San Juan, Chile [19]. The identification of lavendulan specimen is confirmed by single crystal X-ray diffraction techniques [20]. Raman spectroscopy has also reliable performance to characterise lavendulan, and infrared spectra reported [21]. This mineral was found as alteration products in ancient slag heaps and used for colourant effects in cosmetics of ancient Egyptians [21]. The discovery of lavendulan in Chinese painting is seldom reported. It is detected in the wall painting of Cave 11 of Yungang Grotto (云冈石窟), Shanxi Province and colored drawing on timber structure of Kumbum Monastery (塔尔寺), Qinghai Province [22]. Lavendulan is also found in paint layers of statues from Anyue Grotto (安岳石窟), Sichuan Province [23]. We find lavendulan on paintings of Maidservant figures in the Saint Mother's
Hall of Jinci Temple (晋祠), Shanxi Province. In these papers, it is still unclear that lavendulan may be formed by the degradations of other pigments containing $\mathrm{Cu}$ and As.

Naturally, taking physical and chemical conditions of their usage and storage into account, pigments in wall paintings and polychrome statues are much more subjected to the environment, even in complex conditions including high humidity or dissolved salts. Even some of these are well studied above, more tracking and new investigations are still needed and crucial for the conservation field.

In 2016, China's National Cultural Heritage Administration launched a large-scale perseveration demonstration projects for the Buddhism Grottoes in Sichuan Province and Chongqing Municipality. At that time, a subproject aiming to conserve and restore the Niche of Sakyamuni Entering Nirvana Statue in Great Buddha Bend (Dafowan, 大佛湾) and Polychrome Statues in Little Buddha Bend (Xiaofowan, 小佛湾) at Dazu Rock Carvings (大足石刻) was undertaken by the Chinese Academy of Cultural Heritage. Located outdoors in a long time, the statues have been inevitably suffering from surface weathering, water seepage, rock instabilities, biological erosion, salt corrosion, etc., so the scientific investigation and conservation is becoming urgent. The first step is to investigate the characteristics of the paintings on caved sandstone surface for determining the appropriate intervention treatment. Therefore, the polychrome statue Vairocana Statue in Little Buddha Bend at Dazu Rock Carvings of Chongqing municipality was chosen as a demonstration example.

In this study, a coupling of Raman spectrum and mapping, OM, and SEM-EDS have been applied to identify the composition of original pigments and signs of their degradation in cross sections of color layers from paintings of polychrome statue Vairocana Statue. The information obtained can accelerate a better understanding of the transformation processes which affect the history and stability of paints. Material identification of layer stratigraphy can confirm the date of paintings executed.

\section{Materials and methods \\ Materials}

Outstanding as the pinnacle of Chinese cave temple art from the 9th to 13th centuries, Dazu Rock Carvings were listed as World Cultural Heritage by UNESCO in 1999. The sites located in Dazu District, Chongqing, China, are comprised of the cliffside carvings at Baodingshan, Beishan, Nanshan, Shizhuanshan and Shimenshan. Dazu Rock Carvings are remarkable for their aesthetic quality, their rich diversity of subject matter, both secular and religious, and the light that they shed on everyday life in 
China during this period. They provide outstanding evidence of the harmonious synthesis of Buddhism, Taoism and Confucianism [24].

The culmination of carvings is found on Mount Baoding, consisting of two groups from the late 12th to the mid 13th century, namely, Great Buddha Bend and Little Buddha Bend.

The Vairocana Buddha Statue (measuring $1.92 \times 1.57 \mathrm{~m}$ ) is the Lord Buddha of whole Little Buddha Bend statues. The paintings have been re-painted several times observed by naked eyes and seriously damaged. For examples, they are seen as the numerous colour losses, cracking and crumbling of the pictorial layer. Some paintings become powder-like substances. Dust is deposited on the paint surface, and the cracked areas easily gather the dust from the environment. Sixteen micro samples including blue, green, red, gilding, black and white color are collected from the painting of this statue (Fig. 1).

\section{Methods}

\section{Paint sample preparation}

Sixteen samples, including different paint layer and ground layer, are collected alongside damages. Sample locations are illustrated in Fig. 1. All the samples are mounted as cross section (CS). For cross section preparation, the minute pigments are embedded in epoxy resin (Buehler Epo Thin) and polished with dry abrasive papers down to $0.5 \mu \mathrm{m}$ to obtain sufficiently polished surface. Each layers of these samples are analyzed by Optical microscope (OM), micro-Raman spectroscopy (Raman) and scanning electron microscopy coupled with energy dispersive X-ray spectrometry (SEM-EDS).

\section{Cross section sample analysis}

The samples are observed using a Leica $4000 \mathrm{M}$ optical microscope.

A Horiba Jobin-Yvon Xplora spectrometer coupled with $100 \times$ objective of an Olympus BX-41 microscope is employed for identification of pigments in each painting layers. The $532 \mathrm{~nm}$ green and $785 \mathrm{~nm}$ red laser is used and the spectra is recorded with a resolution of $2 \mathrm{~cm}^{-1}$. The spectra of pigment particles are representative and chosen from at least three different points. Moreover, identifying green pigments, a $532 \mathrm{~nm}$ laser is used and the power is reduced using $1 \%$ filter, to avoid the thermal photodecomposition. The exposure time is 10 s with 20 accumulation.

The cross section samples are coated with carbon and studied under a TESCAN VEGA3 scanning electron microscope, equipped with Bruker XFlash 610M energy dispersive X-ray at an accelerating voltage of $20 \mathrm{kV}$.

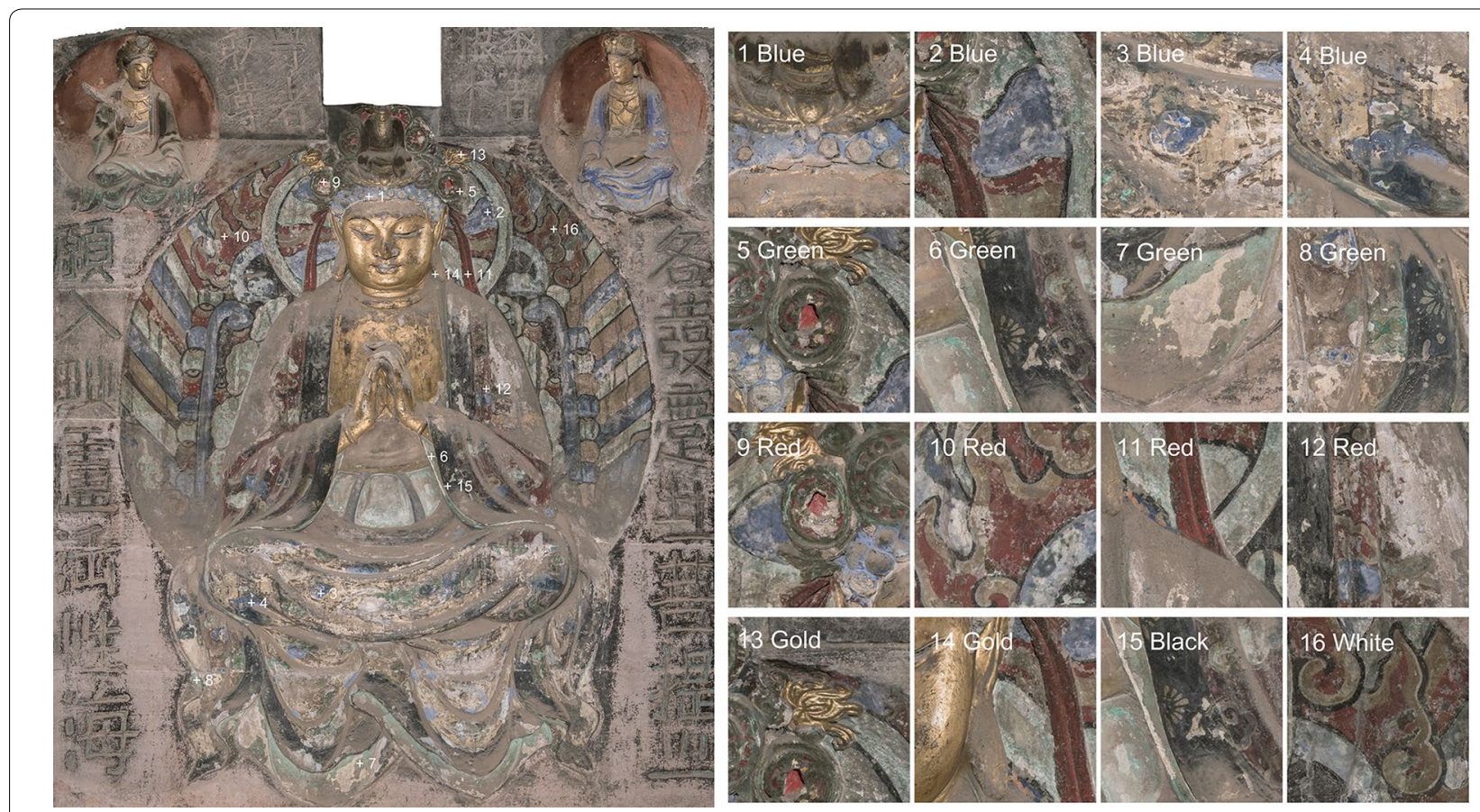

Fig. 1 Vairocana Buddha in the Little Buddha Bend at Dazu Rock Carvings. The sample location for (1-4) blue, (5-8) green, (9-12) red, (13-14) gold, (15) black, and (16) white pigments on the painting 


\section{Results and discussion Paint layers}

The structure and materials of the Vairocana Statue are very complex, including sandstone substrate, gilding and paintings. The components of non-degraded sandstones of the rock carving are feldspar, quartz, plagioclase, calcite, and a small amount of clay [25]. OM and SEM results of multi-layered paint CS1, CS5, CS10, CS11, CS13 and CS16 show delamination phenomena in the paintings, the visible layers are numbered $1-7$ or 8 from the surface to base layer in Fig. 2. Table 1 summarizes multi-paint stratigraphy and layer composition of these samples examined by Raman and EDS.

$\mathrm{OM}$ and BSE images of single-layered paint CS2-4, CS6-8, CS9, CS12, CS14 and CS15 are reported in Additional file 1: Figure S1. Two layers of these ten samples are distinguished along the paint surface to base layer: paint layer close to ground layer. The ground layer is composed of gypsum $\left(\mathrm{CaSO}_{4} \cdot 2 \mathrm{H}_{2} \mathrm{O}\right)$, calcite $\left(\mathrm{CaCO}_{3}\right)$, quartz $\left(\mathrm{SiO}_{2}\right)$ analyzed by Raman and clay by SEM-EDS as the presence of elements e.g. $\mathrm{Na}$, $\mathrm{Mg}, \mathrm{Al}, \mathrm{Si}, \mathrm{S}, \mathrm{Ca}$ and Fe consistent with XRD analysis results [26]. Blue pigment of $\mathrm{CS} 2-4$ is mainly identified as ultramarine blue $\left(\mathrm{Na}_{8}\left[\mathrm{Al}_{6} \mathrm{Si}_{6} \mathrm{O}_{24}\right] \mathrm{S}_{\mathrm{n}}\right)$. Green layer of CS6-8 is mixture of lavendulan, mimetite, cerussite $\left(\mathrm{PbCO}_{3}\right)$, barite $\left(\mathrm{BaSO}_{4}\right)$, whewellite $\left(\mathrm{CaC}_{2} \mathrm{O}_{4} \cdot \mathrm{H}_{2} \mathrm{O}\right)$ and gypsum. Red layer of CS9 and CS12 is composed of vermilion, and black layer of CS 15 contains carbon (C).
For CS13, the ground layer used to bond gold layer are defined as the base layer close to the sandstone substrate. This layer could be subdivided into three sub-layers, corresponding to red layer 2, black layer 3 and gray layer 4 in Fig. 2 CS13. The layer is composed of organic binding media and inorganic materials. The binding media is confirmed as a mixture with Chinese lacquer by using infrared spectrometry (IR) and tung oil by gas chromatography-mass spectrometry (GC/MS) [27]. Vermilion is added into the binding media in red layer to high the gold gloss. Black-gray lacquer layer mixed with quartz and clay aim to smooth the adhered surface of sandstone.

\section{Green copper arsenite pigments}

To highlight the representativeness of the results, four green pigment samples of CS5, CS6, CS7 and CS8 are selected. These samples cover the important units of green pigment usage in the statue. For each sample, Raman analysis focused on the green layer to identify the components.

The spectra taken from CS5 are shown in Fig. 3, the positions and the vibrational assignments of the main bands listed in Table 2. The characteristic bands of emerald green particles are detected at 154, 175, 217, 242, 294, 325, 371, 429, 492, 539 and $950 \mathrm{~cm}^{-1}$ (Fig. 3a). The feature assigned to the acetate group is evident at $950 \mathrm{~cm}^{-1}$ corresponding to $\mathrm{C}-\mathrm{C}$ stretching, and low wavenumber is due to the arsenite moiety [28]. The spectra exhibit
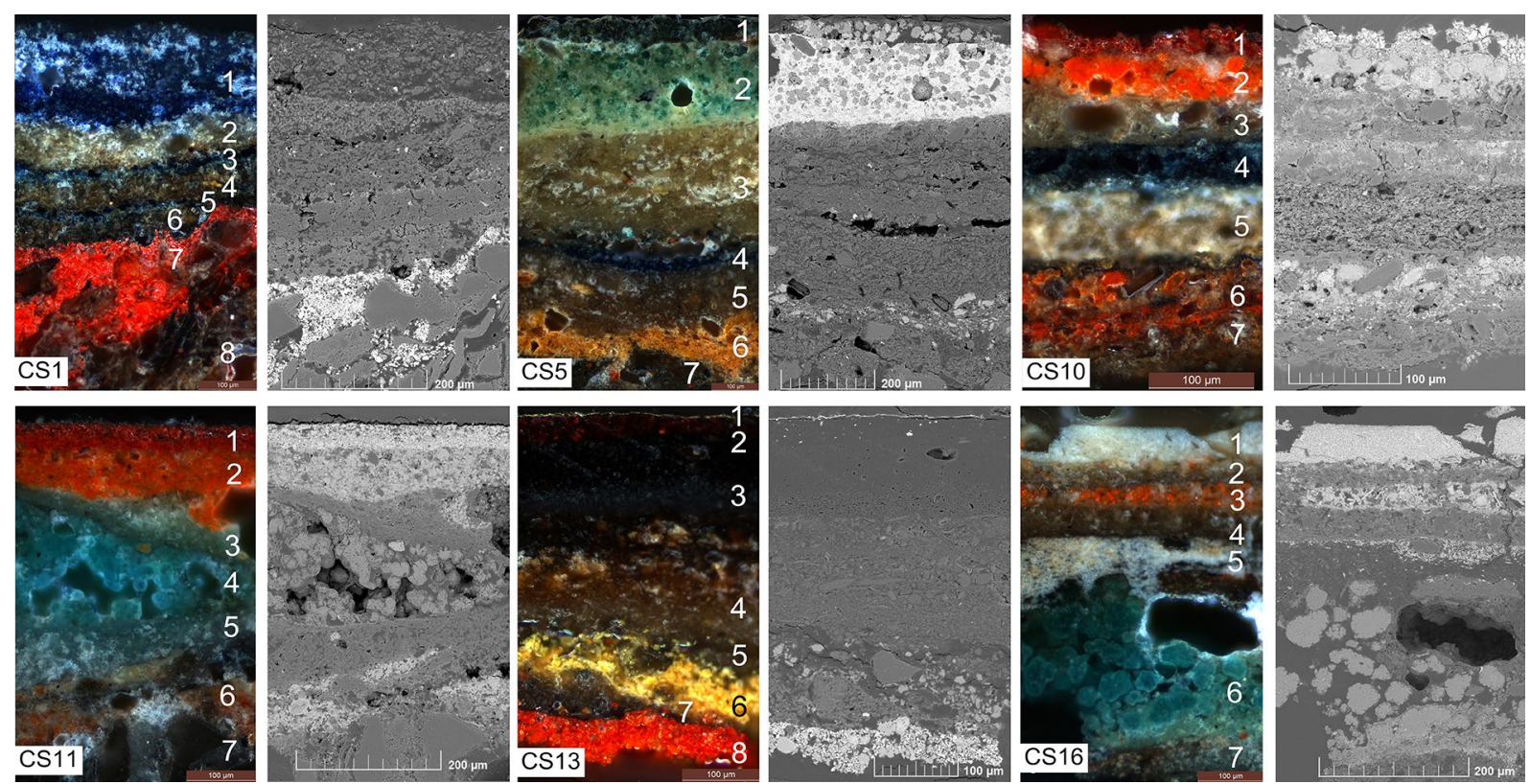

Fig. 2 OM and BSE images of cross section samples revealing paint stratigraphy. Perceived surface colors of samples: CS1 blue, CS5 green, CS10 red, CS11 red, CS13 gold, CS16 white 
Table 1 Layer stratigraphy and components of cross sections in Fig. 2

\begin{tabular}{|c|c|c|c|c|c|c|c|}
\hline Sam. & Layer & Colour & Identified components & Sam. & Layer & Colour & Identified components \\
\hline \multirow[t]{8}{*}{$\begin{array}{l}\text { CS1 } \\
\text { Blue }\end{array}$} & 1 & Blue & Ultramarine blue & \multirow[t]{8}{*}{$\begin{array}{l}\text { CS5 } \\
\text { Green }\end{array}$} & 1 & Green & $\begin{array}{l}\text { Emerald green, lavendulan, mimetite, cerussite, gypsum, } \\
\text { barite, whewellite }\end{array}$ \\
\hline & 2 & Gray & Gypsum, calcite, quartz, clay & & 2 & Green & Lavendulan, mimetite, cerussite, gypsum, barite, whewellite \\
\hline & 3 & Blue & Ultramarine blue & & 3 & Gray & Gypsum, calcite, quartz, clay \\
\hline & 4 & Gray & Gypsum, calcite, quartz, clay & & 4 & Blue & Ultramarine Blue \\
\hline & 5 & Blue & Ultramarine blue & & 5 & Gray & Gypsum, calcite, quartz, clay \\
\hline & 6 & Gray & Gypsum, calcite, quartz, clay & & 6 & Yellow & Orpiment \\
\hline & 7 & Red & Vermilion & & 7 & Gray & Sandstone substrate \\
\hline & 8 & Gray & Sandstone substrate & & & & \\
\hline \multirow{7}{*}{$\begin{array}{l}\text { CS10 } \\
\text { Red }\end{array}$} & 1 & Red & Vermilion & \multirow{7}{*}{$\begin{array}{l}\text { CS11 } \\
\text { Red }\end{array}$} & 1 & Red & Vermilion \\
\hline & 2 & Orange & Red lead & & 2 & Orange & Red lead \\
\hline & 3 & Gray & Gypsum, calcite, quartz, clay & & 3 & Gray & Quartz, clay \\
\hline & 4 & Black & Carbon, calcite, lead white & & 4 & Green & Lavendulan \\
\hline & 5 & Gray & Gypsum, calcite, lead white, clay & & 5 & Gray & Quartz, clay \\
\hline & 6 & Orange & Red lead, vermilion & & 6 & Orange & Red lead \\
\hline & 7 & Gray & Sandstone substrate & & 7 & Gray & Sandstone substrate \\
\hline \multirow{8}{*}{$\begin{array}{l}\text { CS13 } \\
\text { Gold }\end{array}$} & 1 & Gold & Gold layer (Au 99.3 wt \%, Ag 0.7 wt \%) & \multirow{7}{*}{$\begin{array}{l}\text { CS16 } \\
\text { White }\end{array}$} & 1 & White & Cerussite \\
\hline & 2 & Red & Ground layer & & 2 & Gray & Quartz, clay \\
\hline & 3 & Black & Ground layer & & 3 & Orange & Red lead \\
\hline & 4 & Gray & Ground layer & & 4 & Gray & Quartz, clay \\
\hline & 5 & Gray & Quartz, clay & & 5 & White & Cerussite, gypsum, calcite, quartz, clay \\
\hline & 6 & Yellow & Orpiment & & 6 & Green & Malachite, atacamite \\
\hline & 7 & Gray & Quartz, clay & & 7 & Gray & Sandstone substrate \\
\hline & 8 & Red & Vermilion, red lead & & & & \\
\hline
\end{tabular}

the characteristic bands belonging of lavendulan located at 178, 226, 278, 342, 410, 544, $853 \mathrm{~cm}^{-1}$ (Fig. 3b). The spectra consists of $v_{1}\left(\mathrm{AsO}_{4}\right)$ at $854, v_{2}$ at 345 and $v_{4}$ at $545 \mathrm{~cm}^{-1}$ [21]. The As-containing phases in green layer are mimetite and cerussite. The mimetite is indicated by a strong band corresponding to $v_{1}$ modes of $\mathrm{AsO}_{4}$ at $813 \mathrm{~cm}^{-1}$ (Fig. 3c) and cerussite by a strong band corresponding to $v_{1}$ modes of $\mathrm{CO}$ at $1054 \mathrm{~cm}^{-1}$ (Fig. 3c, d) in the Raman spectra [29]. The main characteristic bands of whewellite are observed at 1464 with a second band at $1491 \mathrm{~cm}^{-1}$ assigned to the $\mathrm{CO}$ stretching mode and $897 \mathrm{~cm}^{-1}$ to the $\mathrm{C}-\mathrm{C}$ stretching mode (Fig. 3d) [30]. Raman signal also display the occurrence of gypsum and baryte (Fig. 3c, d).

All four cross sections show that green layer is mainly composed of lavendulan, together with mimetite, cerussite, gypsum, barite and whewellite. A small quantity of emerald green particles are present only in the lower part (layer 2, Fig. 2 CS5) of green layer. Apart from lavendulan and emerald green, no other copper-arsenic containing pigments are detected in these cross sections.

The finding of lavendulan and mimetite is of an exceptional importance. Especially, there is a complete lack of historical evidence of lavendulan used as pigment. The crucial question is whether the lavendulan represents an intentionally used pigment or a secondary phase formed by degradation of other $\mathrm{Cu}$-As-containing pigments, such as emerald green.

To explore this issue, CS5 is carefully selected from the previously mentioned green samples, hope to obtain accurate information regarding the morphology and distribution of the residual emerald green and lavendulan particles.

Further observations with OM and SEM-BSE for CS5 show the upper part (layer 1 in Fig. 4a) of the green layer losing the green coloration hue comparing with the lower part (layer 2 in Fig. 4a) caused by the absence of emerald green. The lavendulan particles show single plates radiating from center to edges with a diameter of $\sim 10 \mu \mathrm{m}$ and spherulites formed by the plates overlapping or intersecting at the center in Fig. 4b, c. Although lavendulan particles occur with color of pale blue (Fig. 4b), their general crystal habit and structure is consistent with that of emerald green [13]. Nevertheless, the natural lavendulan forms bright blue crusts, spherules and thin rectangular platelets which are flexible and have a low Mohs hardness (2.5) and excellent cleavage parallel to the platy face [20]. These results suggest that lavendulan is a degradation 


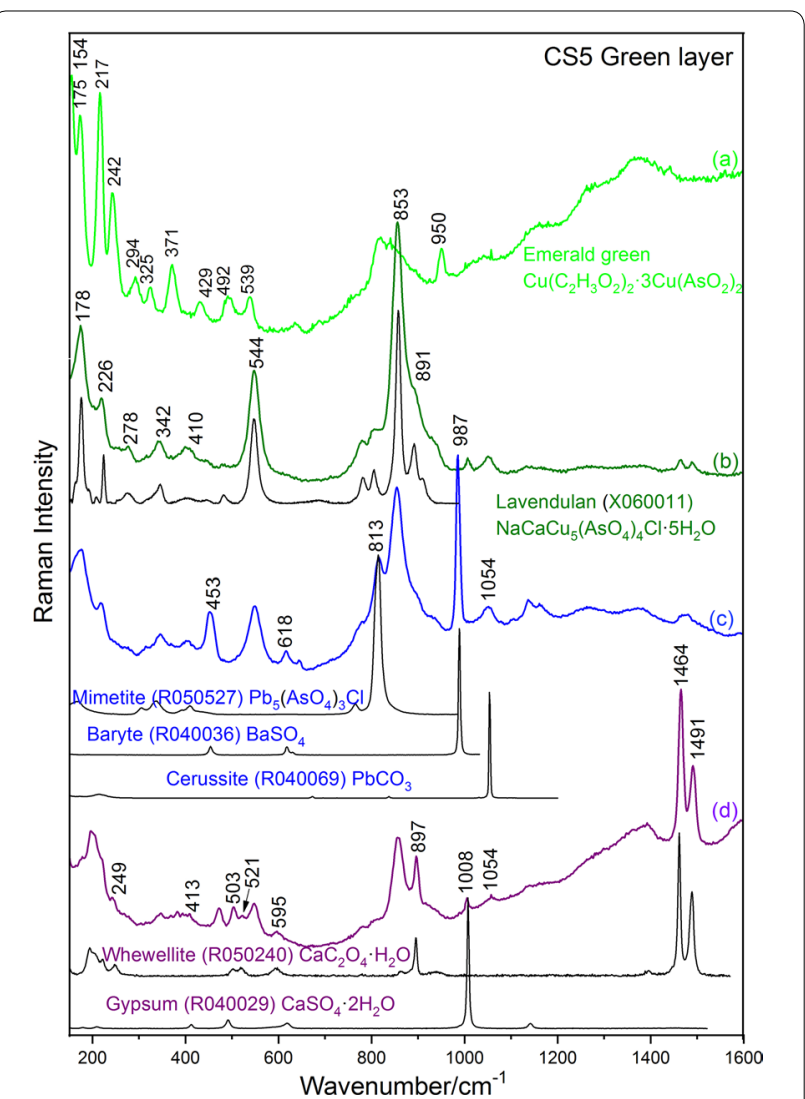

Fig. 3 Raman spectra from green layer of CS5: a-d show characteristic peaks for emerald green, lavendulan, mimetite, baryte, cerussite; whewellite and gypsum. Black reference spectrums from RRUFF open database product of emerald green. The elemental maps of the green layer corresponding to BSE image (Fig. 4d) show the distribution of copper, arsenic, sodium, calcium and chlorine (Fig. 4e-i). The arsenic is not confined to the green particles, and migrates throughout the whole green layer, while the copper distribution is limited to particles. This is similar to observation of the migration of arsenic from the arsenic-containing pigments to paint layers [31, 32]. Furthermore, the absence of arsenic in the blue, gold, red and black samples and paints excludes the possibility of arsenic introduced from the surrounding environment to the green paint. An explanation for the presence of arsenic in the green layer could be deriving from degraded emerald green. The distributions of $\mathrm{Na}, \mathrm{Ca}$ and $\mathrm{Cl}$ in green layer also suggest these elements introduced from the surrounding environment and then react with $\mathrm{Cu}$ and $\mathrm{As}$ to form lavendulan.

Based on the preliminary OM and Raman results, the residual emerald green particles are identified in small quantities at the lower part (layer 2, Fig. 2 CS5) of green layer. A representative subarea is selected and analyzed
Table 2 Main Raman characteristic bands for phases of CS5 green layer

\begin{tabular}{ll}
\hline Raman $\left(\mathbf{c m}^{\mathbf{- 1}}\right)$ & $\begin{array}{l}\text { Vibrational } \\
\text { assignment }\end{array}$ \\
\hline Lavendulan & $\mathrm{v}_{1}\left(\mathrm{AsO}_{4}\right)$ \\
853 & $\mathrm{v}_{4}\left(\mathrm{AsO}_{4}\right)$ \\
544 & $\mathrm{v}_{2}\left(\mathrm{AsO}_{4}\right)$ \\
410 & $\mathrm{v}_{2}\left(\mathrm{AsO}_{4}\right)$ \\
342 & \\
Baryte & $\mathrm{v}_{1}\left(\mathrm{SO}_{4}\right)$ \\
987 & $\mathrm{v}_{4}\left(\mathrm{SO}_{4}\right)$ \\
618 & $\mathrm{v}_{2}\left(\mathrm{SO}_{4}\right)$ \\
453 & \\
Gypsum & $\mathrm{v}_{1}\left(\mathrm{SO}_{4}\right)$ \\
1008 & $\mathrm{v}_{2}\left(\mathrm{SO}_{4}\right)$ \\
413 & \\
Cerussite & $\mathrm{v}_{1}(\mathrm{CO})$ \\
1054 & \\
Whewellite & $\mathrm{v}_{\mathrm{a}}(\mathrm{C}=\mathrm{O})$ \\
1491 & $\mathrm{v}_{\mathrm{a}}(\mathrm{C}=\mathrm{O})$ \\
1464 & $\mathrm{v}(\mathrm{C}-\mathrm{C})$ \\
897 & $\mathrm{v}(\mathrm{M}-\mathrm{O})$ \\
595 &
\end{tabular}

by using Raman mapping. Distributions of crystalline phases of this area show more details in Fig. 5. Emerald green is confirmed as green pigment and surround by cerussite as shown in Fig. 5a, b. Next to emerald green (point 1), distributions of lavendulan (point 2, 3 and 4) are quite different (see Fig. 5c). Mimetite is found in the vicinity of green particles and shows a higher abundance in the areas around lavendulan particles (especially point 3 ) than that around emerald green (see Fig. 5d). These results suggest arsenic derived from the degraded emerald green particles must have reacted with cerussite to form mimetite as secondary products.

\section{Green copper hydroxychloride pigments}

Regarding the green layer of CS16, layer structure and composition are investigated by Raman, OM and SEM-EDS.

Raman analysis (Fig. 6) shows the existence of atacamite and malachite in the green layer (layer 6, Fig. 2 CS16). The positions and the vibrational assignments of the main bands for atacamite are listed in Table 3. The presence of atacamite can be concluded from Raman characteristic bands in the range of $145-972 \mathrm{~cm}^{-1}$ and $3328-3433 \mathrm{~cm}^{-1}$ which coincide with the published literature [33], three intense bands at the identical positions are observed at 972,902 and $818 \mathrm{~cm}^{-1}$, the bands between 800 and $1000 \mathrm{~cm}^{-1}$ attributed to $\mathrm{Cu}-\mathrm{OH}$ and 

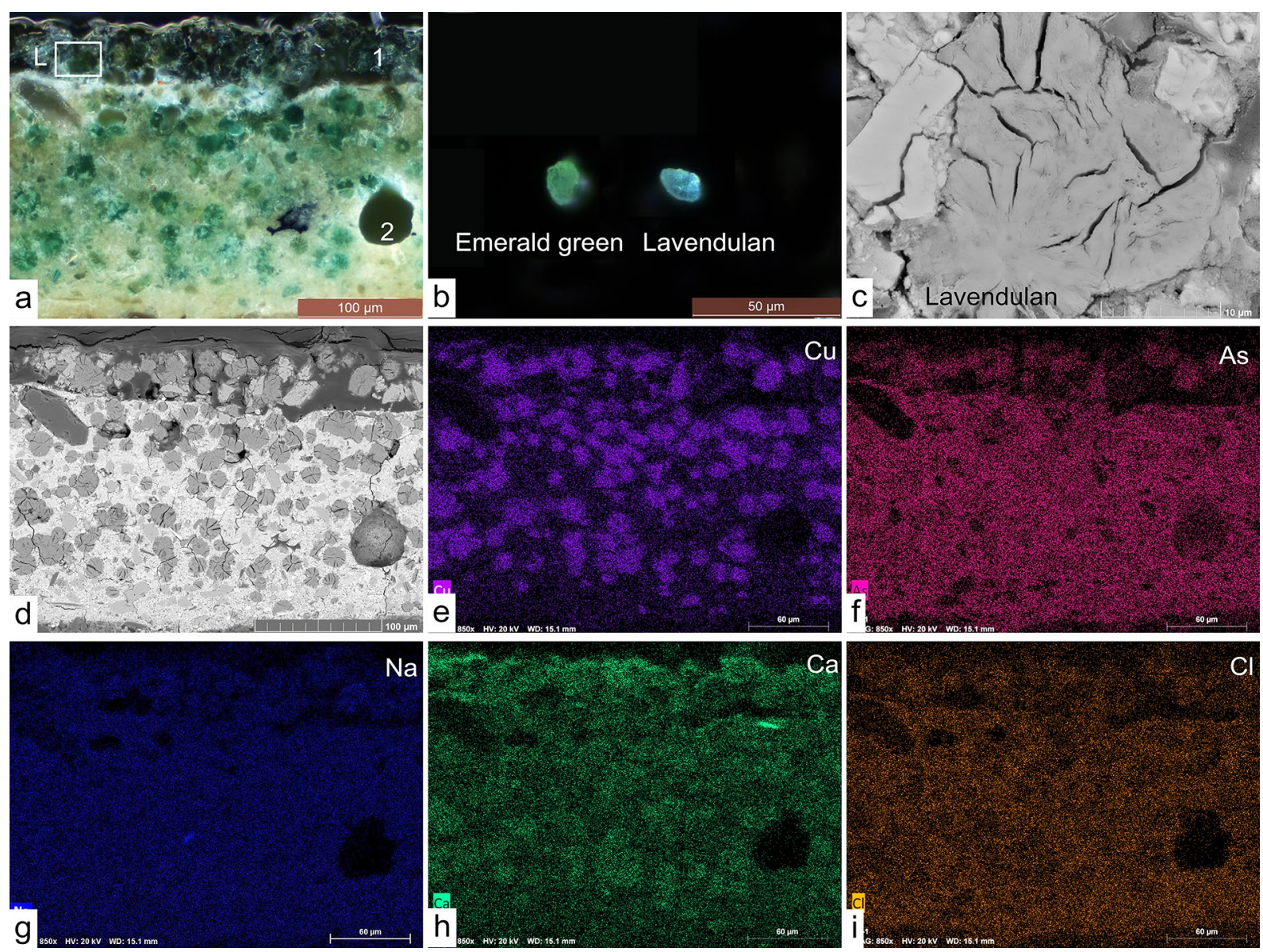

Fig. 4 Green layer (layer 1 and layer 2, Fig. 2 CS5): a optical microscopic image of green layer, b optical microscopic image of particles show the loss of green coloration of emerald green degraded into lavendulan, c SEM-BSE image of lavendulan particles, $\mathbf{d}$ SEM-BSE image of green layer, and elemental maps of $\mathbf{e}$ copper, $\mathbf{f}$ arsenic, $\mathbf{g}$ sodium, $\mathbf{h}$ calcium and $\mathbf{i}$ chlorine show that arsenic migrated out the particle and diffusion within the whole green layers while the occurrence of copper is limited within green particles

$\mathrm{OH}$ bends; the intense band occurs at $511 \mathrm{~cm}^{-1}$, the bands below $600 \mathrm{~cm}^{-1}$ assigned to $\mathrm{O}-\mathrm{Cu}-\mathrm{O}$ and $\mathrm{Cl}-$ $\mathrm{Cu}-\mathrm{Cl}$ modes; three bands at 3328,3349 and $3433 \mathrm{~cm}^{-1}$ assigned to $\mathrm{OH}$ stretches.

Figure $7 \mathrm{a}, \mathrm{b}$ and $\mathrm{c}$ mainly show that numerous atacamite particles appear as aggregates or masses, while malachite particles sporadically occur in the layer. The synthetic atacamite particles are found to be spherical with dark spots in the center under the PLM [34, 35]. Figure $7 \mathrm{~b}-\mathrm{d}$ and g reveal nearly spherical particles, typical for synthetic atacamite. Malachite could be obtained as a by-product of preparation of synthetic atacamite. Artificial copper trihydroxychlorides could be the most popular green pigments for wall painting and architecture from North Dynasty (386-581 CE) until late Qing Dynasty (1840-1911 CE) [36]. In addition, the element maps of chlorine associated with copper (Fig. 7e, f, h, i) show delamination phenomena in the green layer is invisible, suggesting the green layer was painted only one time other than repainted using the two kinds of green pigments.

\section{Discussion on dating}

Emerald green is a brilliant green pigment first synthesized by Willem Sattler in 1814. Emerald green particles exist in a great variety of crystalline assemblages that are organized as agglomerates of crystal platelets in the form of rosettes or spherulites [13]. It was widely used in China as watercolor in pith paper works and in scroll paintings from the 1850s onwards [37]. Ultramarine blue shows rounded anisotropic particles of homogeneous sizes $(\approx 2 \mu \mathrm{m})$, suggesting the artificial origin of lapis lazuli [38] are used in the out layer of the painted statues. Artificial ultramarine blue was invented by Guimet in 1828 and its commercial production evolved soon after 1830 [39]. Then ultramarine blue was introduced from Europe 


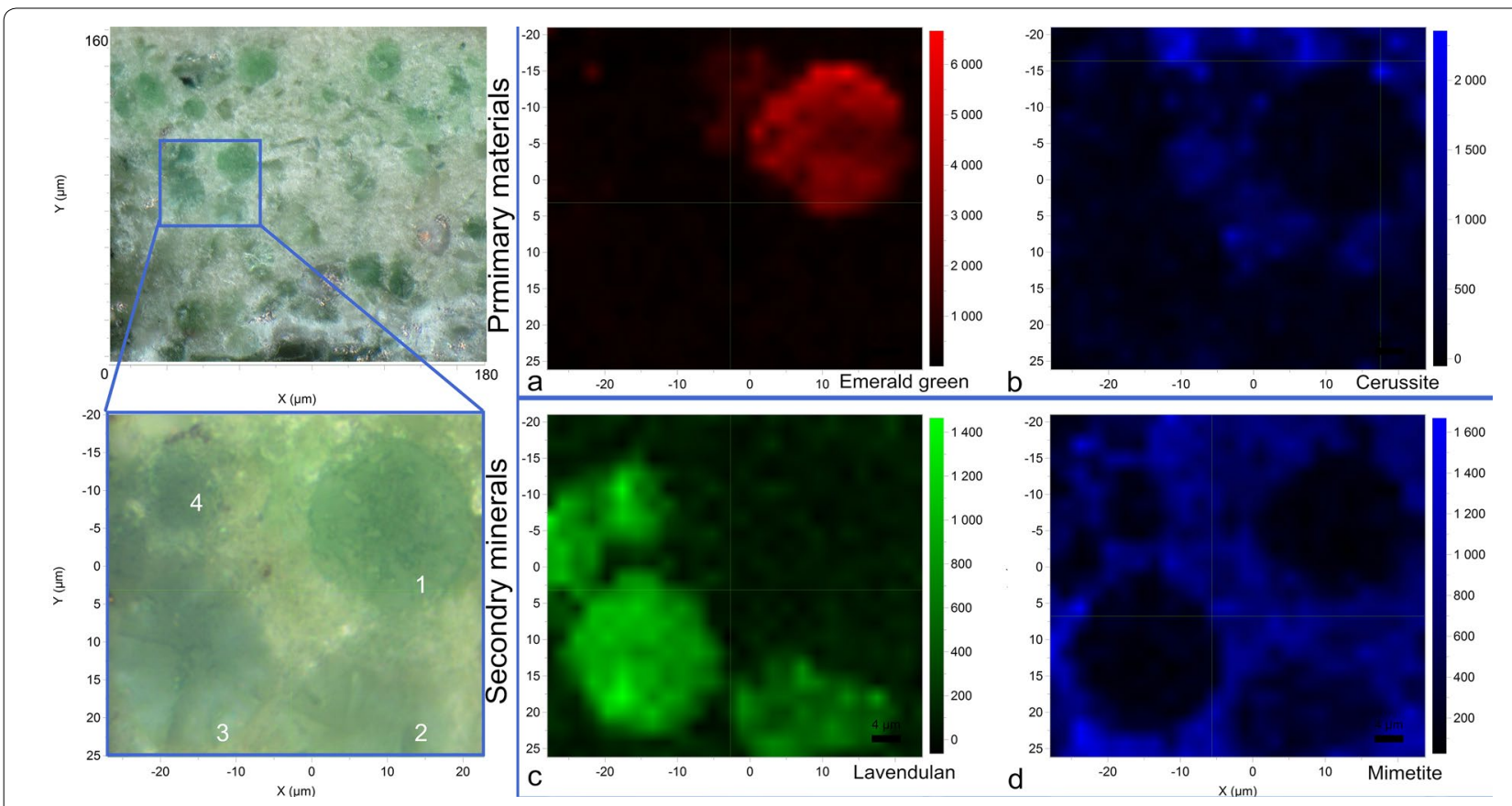

Fig. 5 Raman mapping of a sub area (see rectangle) in the lower part of CS5 green layer: a emerald green and $\mathbf{b}$ cerussite, assumed to be originally present in green layer; $\mathbf{c}$ lavendulan and $\mathbf{d}$ mimetite as to secondary minerals, formed in situ

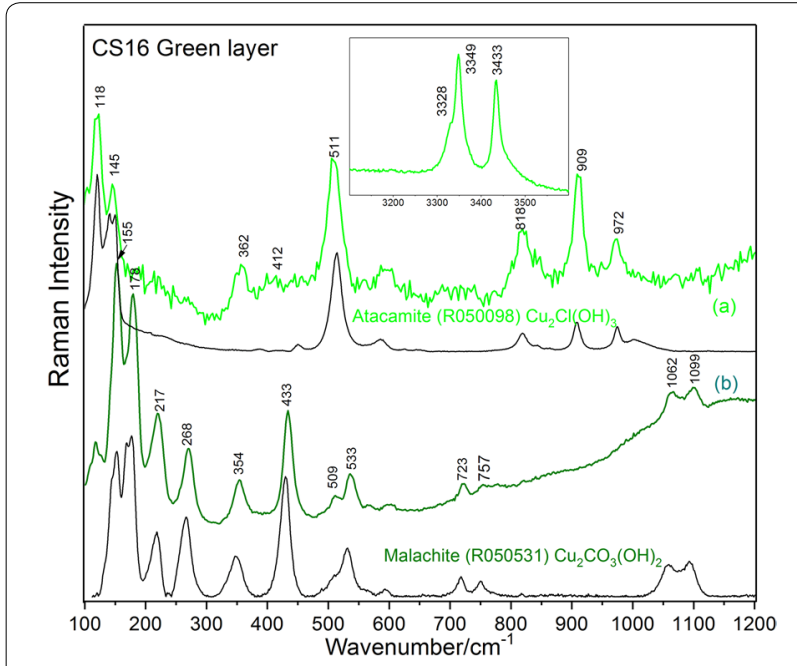

Fig. 6 Raman spectra from green layer of CS16: a atacamite and $\mathbf{b}$ malachite. Black reference spectra from RRUFF open database

into China in late Qing Dynasty (1840-1912 CE), and the importation lasted until 1927 when Chinese chemists Dai A and Ling $\mathrm{Z}$ synthesized this pigment [40].

The statues in the Little Buddha Bend at Dazu Rock Carving were excavated during the Southern Song Dynasty (1127-1279 CE) [41]. Religious paintings in China usually undergo heavy repairs and even re-painting in different period. As the layer stratigraphy shown
Table 3 Main Raman characteristic bands for atacamite of CS16 green layer

\begin{tabular}{ll}
\hline Raman $\left(\mathbf{c m}^{-\mathbf{1}}\right)$ & $\begin{array}{l}\text { Vibrational } \\
\text { assignment }\end{array}$ \\
\hline 3433 & $\vee(\mathrm{OH})$ \\
3349 & $\vee(\mathrm{OH})$ \\
3328 & $\vee(\mathrm{OH})$ \\
972 & \\
909 & $\delta(\mathrm{CuOH})$ \\
818 & \\
511 & $\vee(\mathrm{CuO})$ \\
412 & $\vee(\mathrm{CuCl})$ \\
145 & $\delta(\mathrm{OCuO})$ \\
\hline
\end{tabular}

(Fig. 2), for more than 800 years so far, the Vairocana Buddha statue has been painted at least four times. Concerning these documents above, the most recent painting of the statue may be executed after late 1850s, based on the date of the wide use of emerald green.

Because the date of the invention and wide use in China of emerald green and ultramarine blue were nearing, they appeared co-localized in Chinese paintings. In addition, consistent with the recent literature on this topic [1618 ], the rare nature of mimetite minerals strongly suggests that they are secondary products. Once more this information suggests emerald green was used as original pigment other than lavendulan (secondary products). 

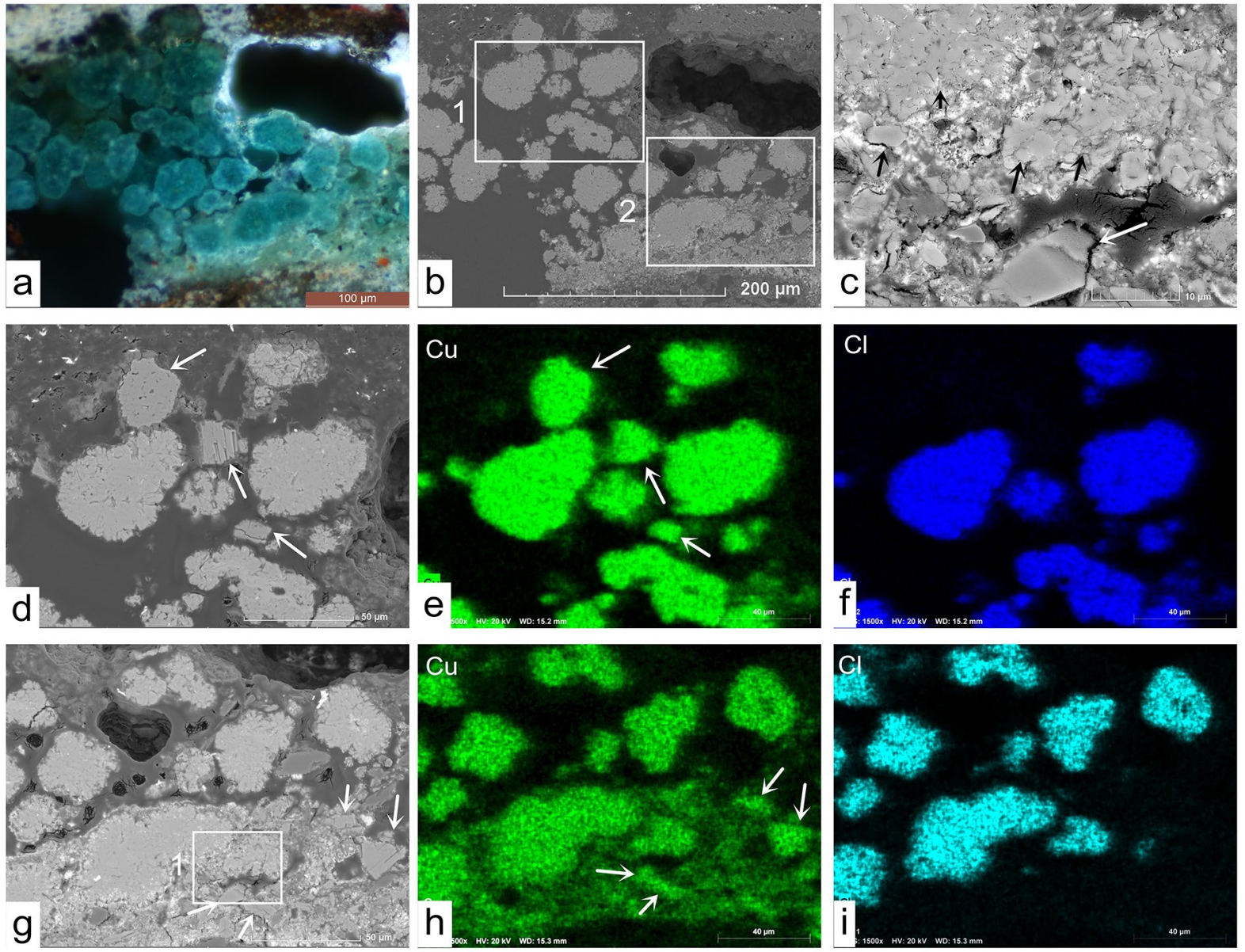

Fig. 7 Microscopic images of green layer (layer 6 in Fig. 2f) of CS16: a OM, b SEM-BSE, c BSE image enlarged rectangle 1 in g, atacamite obviously seen with black arrows and malachite with white arrows, $\mathbf{d}$ BSE image (see rectangle 1 in b) and elemental maps of e copper and $\mathbf{f}$ chlorine, $\mathbf{g}$ BSE image (see rectangle 2 in $\mathbf{b}$ ) and elemental maps of $\mathbf{h}$ copper and $\mathbf{i}$ chlorine show the occurrence of malachite (white arrows)

\section{Degradation progress of emerald green}

The Vairocana Buddha statue locates in the Holy Longevity Sites, where the air circulation is poor because of the semi-closed building structure. Relative humidity in the Dazu Rock Carvings is very high and can reach above $85 \%$ from July to September, even oversaturated to form condensation water with $\mathrm{pH}$ scale at 6 on the surface of statues [42]. When exposed to such conditions, degradation phenomena of pigments can occur, namely transformation from emerald green to lavendulan in the paint surface. It can be explained as follows:

The degradation of emerald green can occur under acidic conditions provided by the environment [15]. Emerald green $\left(\mathrm{Cu}\left(\mathrm{C}_{2} \mathrm{H}_{3} \mathrm{O}_{2}\right)_{2} \cdot 3 \mathrm{Cu}\left(\mathrm{AsO}_{2}\right)_{2}\right)$ can release acetic acid $\left(\mathrm{CH}_{3} \mathrm{COOH}\right)$ together with arsenite $\left(\mathrm{HAsO}_{2}\right)$ and copper ions $\left(\mathrm{Cu}^{2+}\right)$ in the slightly acidic environment (Eq. 1). In the next step, the arsenite ions $\left(\left(\mathrm{AsO}_{2}\right)^{-}\right)$are oxidized to arsenate ions $\left(\left(\mathrm{AsO}_{4}\right)^{3-}\right)$ (Eq. 2) [14, 43]. The chemical transformation to the arsenate from arsenite clearly is an oxidation process since the As(III)-species are originally in emerald green that change to As(V)species. Standard reduction potentials ( $\mathrm{E}^{0}$ values) at $298.15 \mathrm{~K}$, pressure of $101.325 \mathrm{kPa}$ (1 atm) for half-reactions of this redox reaction are as follow: $\mathrm{E}^{0}=0.40 \mathrm{~V}$ for $\mathrm{O}_{2}+2 \mathrm{H}_{2} \mathrm{O}+4 \mathrm{e}^{-} \rightarrow 4 \mathrm{OH}^{-}$[44] and $\mathrm{E}^{0}=-0.67 \mathrm{~V}$ for $\left(\mathrm{AsO}_{4}\right)^{3-}+2 \mathrm{H}_{2} \mathrm{O}+2 \mathrm{e}^{-} \rightarrow\left(\mathrm{AsO}_{2}\right)^{-}+4 \mathrm{OH}^{-} \quad$ [45]. This suggest oxygen has the plenty thermodynamic potential to oxidize $\left(\mathrm{AsO}_{2}\right)^{-}$to $\left(\mathrm{AsO}_{4}\right)^{3-}$. The last step involves the reaction of $\left(\mathrm{AsO}_{4}\right)^{3-}$ and $\mathrm{Cu}^{2+}, \mathrm{Na}^{+}, \mathrm{Ca}^{2+}$ and $\mathrm{Cl}^{-}$which triggers the formation of lavendulan $\left(\mathrm{NaCaCu}_{5}\left(\mathrm{AsO}_{4}\right)_{4} \mathrm{Cl} \cdot 5 \mathrm{H}_{2} \mathrm{O}\right)$ (Eq. 3). The formation of lavendulan needs acid environment [46], this could be supplied by pollution air and acid rain surrounding the grotto. 


$$
\begin{aligned}
& \mathrm{Cu}\left(\mathrm{C}_{2} \mathrm{H}_{3} \mathrm{O}_{2}\right)_{2} \cdot 3 \mathrm{Cu}\left(\mathrm{AsO}_{2}\right)_{2}+8 \mathrm{H}^{+} \\
& \rightarrow 4 \mathrm{Cu}^{2+}+6 \mathrm{HAsO}_{2}+2 \mathrm{CH}_{3} \mathrm{COOH} \\
& 2\left(\mathrm{AsO}_{2}\right)^{-}+2 \mathrm{H}_{2} \mathrm{O}+\mathrm{O}_{2} \rightarrow 2\left(\mathrm{AsO}_{4}\right)^{3-}+4 \mathrm{H}^{+} \\
& 5 \mathrm{Cu}^{2+}+\mathrm{Na}^{+}+\mathrm{Ca}^{2+}+4\left(\mathrm{AsO}_{4}\right)^{3-}+\mathrm{Cl}^{-}+5 \mathrm{H}_{2} \mathrm{O} \\
& \rightarrow \mathrm{NaCaCu}_{5}\left(\mathrm{AsO}_{4}\right)_{4} \mathrm{Cl} \cdot 5 \mathrm{H}_{2} \mathrm{O}
\end{aligned}
$$

Cerussite is identified as extender mineral added to the paint, which enwraps the emerald green by using Raman mapping. The dissolution of cerussite $\left(\mathrm{PbCO}_{3}\right)$ occur in the aqueous phase which can be enhanced in acidic solution and releases the $\mathrm{Pb}^{2+}$ ions. The acidic groups from environment are sufficient to promote the dissolution process [47], with consume of free protons and release of $\mathrm{CO}_{2}$ (Eq. 4) [16]. The solvated arsenate ions $\left(\left(\mathrm{AsO}_{4}\right)^{3-}\right)$ that are supplied from the hydrolysis of emerald green migrating toward $\mathrm{Pb}^{2+}$ ions react with $\mathrm{Cl}^{-}$ions to produce the precipitation of mimetite $\left(\mathrm{Pb}_{5}\left(\mathrm{AsO}_{4}\right)_{3} \mathrm{Cl}\right)$ (Eq. 5). Results of X-ray diffraction analysis show the content of $\mathrm{NaCl}$ in the weathered products from the sandstone of Dazu Rock Carvings is about $2.36 \mathrm{wt} \%$ and the groundwater types in this area include $\mathrm{Ca} \cdot \mathrm{Mg}-\mathrm{HCO}_{3} \cdot \mathrm{SO}_{4}$ or $\mathrm{Ca} \cdot \mathrm{Na}-\mathrm{HCO}_{3} \cdot \mathrm{Cl}$ [48]. These chloride ions in the weathered products and groundwater are available for the formation of mimetite.

$$
\begin{aligned}
& \mathrm{PbCO}_{3}+2 \mathrm{H}^{+} \rightarrow \mathrm{Pb}^{2+}+\mathrm{CO}_{2}+\mathrm{H}_{2} \mathrm{O} \\
& 5 \mathrm{~Pb}^{2+}+\mathrm{Cl}^{-}+3\left(\mathrm{AsO}_{4}\right)^{3-} \rightarrow \mathrm{Pb}_{5}\left(\mathrm{AsO}_{4}\right)_{3} \mathrm{Cl}
\end{aligned}
$$

Simultaneously, calcium oxalate, e.g. whewellite $\mathrm{CaC}_{2} \mathrm{O}_{4} \cdot \mathrm{H}_{2} \mathrm{O}$, is also founded together with lavendulan by Raman (Fig. 3d). Oxalate salts are formed by calcium ions reaction with oxalate ions over a wide $\mathrm{pH}$ range, and commonly occur in art objects. The source of oxalate may be considered as chemical result [49, 50], a product of the oxidative degradation of organic binders [51, 52].

In this study, emerald green has low permanence in the environment of high moisture and soluble salt. This work may help the scholars draw attention to the existence of degradation phase when investigating pigments in complex environment system, e.g. emerald green in damp and salt containing conditions. It also helps scholars rethink about rare minerals as original pigments or degradation products. Because of wide application of emerald green in China, rare copperarsenic containing minerals could have a high propensity to be identified as degradation products in the paintings after the late Qing Dynasty. Synthetic pigment is crucial for interpreting the historical context of cultural objects, especially for the dating.

\section{Conclusion}

In the conservation field of heritage science, study on degradation or corrosion of paint materials e.g. pigments play a vital role in solving key questions of conservation, restoration and storage. In this study, secondary arsenate minerals, namely lavendulan and mimetite, are formed due to the degradation of emerald green and cerussite in the slightly acid and highly humid conditions. This processes appear to: formation of arsenate and copper ions as a result of degradation of emerald green; migration of these ions including partially arsenate ions towards the surrounding area where dissolution of $\mathrm{Pb}^{2+}$ ions from cerussite and $\mathrm{Cl}^{-}$ ions from environment to product precipitation of mimetite; copper ions remaining in their original place together with arsenate ions and $\mathrm{Na}^{+}, \mathrm{Ca}^{2+}, \mathrm{Cl}^{-}$to form lavendulan.

The formation of lavendulan gives rise to a highlight for green copper-arsenic containing pigment identification as once generally considered to be emerald green and in turn remind the scholars rethink about the rare minerals discovered in the painting as pigments or degradation products.

Obtained from identification of painting layer stratigraphy, the information is crucial for understanding the context of cultural heritage objects regarding relative date of creation, painting technique and artists' savoir faire. The analysis of paint cross sections from Vairocana Statue in Dazu Rock Carvings, Chongqing, China reveals an example of discrimination the paint dating via material research results. Ultramarine blue, emerald green, synthetic atacamite, vermilion, red lead, gold foil, orpiment, cerussite, gypsum and barite are identified as pigments. Based on the pigment analysis and historical documents, the paintings of the statue have been executed at least four times and the most recent may be after 1850s.

It also demonstrates that Raman spectroscopy mapping and element mapping corresponding with the layer stratigraphy on paint cross section have reliable performance for identification of the components and discrimination between products resulting from degradation processes, especially in the characterization of pigments in complex conditions. 


\section{Supplementary information}

Supplementary information accompanies this paper at https://doi. org/10.1186/s40494-020-00410-2.

Additional file 1: Figure S1. OM and BSE images of single-layered paint cross sections. Perceived surface colors of samples: CS2 $\sim 4$ blue, CS6 $~ 8$ green, CS9 red, CS12 red, CS14 gold, CS15 black.

\section{Abbreviations}

UNESCO: United Nations Educational, Scientific and Cultural Organization; Raman: Micro-Raman spectroscopy; OM: Optical microscopy; SEM-EDS: Scanning electron microscopy with energy dispersive $X$-ray analysis; CS: Cross section.

\section{Acknowledgements}

The authors wish to express their great gratitude to Miss Fengdan $\mathrm{Hu}$ at the Chinese Academy of Cultural Heritage, Professor Yanxiang Li and Mr. Feng Wang at the University of Science and Technology Beijing for their kind support and assistance with this research. Authors would like to thank the peer reviewers and editors for providing valuable feedback.

\section{Authors' contributions}

QM provided support and guidance for this study. ZL performed the analysis. $\mathrm{ZL}, \mathrm{LW}$ and $\mathrm{HC}$ carried out literature. All authors read and approved the final manuscript.

\section{Funding}

Chinese Ministry of Finance's Special Fund for the Basic Research by Non-Profit Public Research Institutes of Chinese Academy of Cultural Heritage

\section{Availability of data and materials}

The datasets used during this study are available from the corresponding author on reasonable request.

\section{Competing interests}

The authors declare that they have no competing interests.

\section{Author details}

${ }^{1}$ Institute of Cultural Heritage and History of Science \& Technology, University of Science and Technology Beijing, Beijing 100083, China. ${ }^{2}$ Chinese Academy of Cultural Heritage, Beijing 100029, China. ${ }^{3}$ Academy of Dazu Rock Carvings, Chongqing 402360, China. ${ }^{4}$ International Joint Research Laboratory of Environmental and Social Archaeology, Shandong University, Qingdao 266237. Shandong, China. ${ }^{5}$ Institute of Cultural Heritage, Shandong University, Qingdao 266237, Shandong, China.

Received: 17 February 2020 Accepted: 23 June 2020

Published online: 04 July 2020

\section{References}

1. De Meyer S, Vanmeert F, Vertongen R, Van Loon A, Gonzalez V, Van der Snickt G, Vandivere A, Janssens K. Imaging secondary reaction products at the surface of Vermeer's Girl with the Pearl Earring by means of macroscopic X-ray powder diffraction scanning. Herit Sci. 2019;7:67.

2. Coccato A, Moens L, Vandenabeele P. On the stability of mediaeval inorganic pigments: a literature review of the effect of climate, material selection, biological activity, analysis and conservation treatments. Herit Sci. 2017;5:12

3. Švarcová S, Hradil D, Hradilová J, Kočí E, Bezdička P. Micro-analytical evidence of origin and degradation of copper pigments found in Bohemian Gothic murals. Anal Bioanal Chem. 2009;395(7):2037-50.

4. Doménech-Carbó M, Edwards H, Doménech-Carbó A, Hoyo-Meléndez J, Cruz-Cañizares J. An authentication case study: antonio Palomino versus Vicente Guillo paintings in the vaulted ceiling of the Sant Joan del Mercat church (Valencia, Spain). J Raman Spectrosc. 2012;43(9):1250-9.
5. Vandenabeele P, Lambert K, Matthys S, Schudel W, Bergmans A, Moens L. In situ analysis of mediaeval wall paintings: a challenge for mobile Raman spectroscopy. Anal Bioanal Chem. 2005;383(4):707-12.

6. Trentelman K, Stodulski L. Characterization of pararealgar and other lightinduced transformation products from realgar by Raman microspectroscopy. Anal Chem. 1996;68(10):1755-61.

7. Muralha V, Miquel C, Melo M. Micro-Raman study of Medieval Cistercian 12-13th century manuscripts: santa Maria de Alcobaca, Portugal. J Raman Spectrosc. 2012;43(11):1737-46.

8. Ballirano P, Maras A. Preliminary results on the ligh-induced alteration of realgar: kinetics of the process. Plinius. 2002;28:35-6.

9. Smith G, Derbyshire A, Clark R. In situ spectroscopic detection of lead sulphide on a blackened manuscript illumination by Raman microscopy. Stud Conserv. 2002:47(4):250-6.

10. Burgio L, Clark RJ, Firth S. Raman spectroscopy as a means for the identification of plattnerite $\left(\mathrm{PbO}_{2}\right)$, of lead pigments and of their degradation products. Analyst. 2001;126(2):222-7.

11. Feller R. Studies on the darkening of vermilion by light. Rep Stud Hist Art. 1967;1:99-111.

12. Keune K, Boon J. Analytical imaging studies clarifying the process of the darkening of vermilion in paintings. Anal Chem. 2005;77(15):4742-50.

13. Fiedler I, Bayard M. Emerald green and Scheele's green. In: Fitzhugh EW, editor. Artists' pigments, a handbook of their history and characteristics, vol. 3. Oxford: Oxford University Press; 1997. p. 219-71.

14. Keune K, Boon J, Boitelle R, Shimadzu Y. Degradation of Emerald green in oil paint and its contribution to the rapid change in colour of the Descente des vaches (1834-1835) painted by Théodore Rousseau. Stud Conserv. 2013;58(3):199-210.

15. Holakooei P, Karimy A, Nafisi G. Lammerite as a degradation product of emerald green: scientific studies on a rural Persian wall painting. Stud Conserv. 2018:63(7):391-402.

16. Hradil D, Hradilová J, Bezdička P, Švarcová S, Čermáková Z, Košařová V, Němec I. Crocoite $\mathrm{PbCrO}_{4}$ and mimetite $\mathrm{Pb}_{5}\left(\mathrm{AsO}_{4}\right)_{3} \mathrm{Cl}$ : rare minerals in highly degraded mediaeval murals in Northern Bohemia. J Raman Spectrosc. 2014;45(9):848-58.

17. Simoen J, De Meyer S, Vanmeert F, Keyser N, Avranovich E, Van der Snickt G, Van Loon A, Keune K, Janssens K. Combined micro- and macro scale $X$-ray powder diffraction mapping of degraded Orpiment paint in a 17th century still life painting by Martinus Nellius. Herit Sci. 2019;7:83.

18. Vanmeert F, De Keyser N, Van Loon A, Klaassen L, Noble P, Janssens K. Transmission and reflection mode macroscopic $X$-ray powder diffraction imaging for the noninvasive visualization of paint degradation in Still Life Paintings by Jan Davidsz. de Heem. Anal Chem. 2019;91:7153-61.

19. Fleischer M. New mineral names. Am Mineral. 1957;42:117-24.

20. Giester $G$, Kolitsch U, Leverett $P$, Turner P, Williams P. The crystal structures of lavendulan, sampleite, and a new polymorph of sampleite. Eur J Mineral. 2007;19(1):75-93.

21. Frost R, Weier M, Williams, Leverett P, Kloprogge J. Raman spectroscopy of the sampleite group of minerals. J Raman Spectrosc. 2007;38(5):574-83.

22. Chen $X$, Yang Q. Micro-Raman spectroscopy study of three green pigments containing copper and arsenic. Sci Conserv Archaeol. 2015;27(3):84-9.

23. Chen E, Zhang B, Zhao F. Comprehensive analysis of polychrome grotto relics: a case study of the paint layers from anyue, sichuan, china. Anal Lett. 2020;53(9):1455-71.

24. World Heritage Centre. Dazu Rock Carvings. In: World Heritage List. United Nations Educational, Scientific and Cultural Organization; 1999. http://whc.unesco.org/en/list/912/. Accessed 2 Dec 1999.

25. Wang J. Dazu Rock Carving Conservation. Beijing: Cultural Relics Publishing Press; 2009. p. 84-5.

26. Gao F, Zhou X, Zhou H, Li M, Tong H, Liu S. Characterization and analysis of sandstone substrate, mortar layers, gold foils, and paintings of the Avalokitesvara Statues in Dazu County (China). J Cult Herit. 2016;21(3):881-8

27. Wang L, Li Z, Fu Y, Chen H, Wei S. Study in gilding material and technique of Buddhist sculpture on Xiaofowan Site, Baoding Mountain, Dazu Grotoes, Chongqing. Res China's Front Archaeol. 2018;2:359-66.

28. Rosi F, Miliani C, Borgia I, Brunetti B, Sgamellotti A. Identification of nineteenth century blue and green pigments by in situ X-ray fluorescence and micro-Raman spectroscopy. J Raman Spectrosc. 2004;35(8):610-5. 
29. Frost R, Martens W, Kloprogge J, Ding Z. Raman spectroscopy of selected lead minerals of environmental significance. Spectrochim Acta A. 2003;59(12):2705-11.

30. Frost R, Weier M. Raman spectroscopy of natural oxalates at 298 and 77 K. J Raman Spectrosc. 2003;34(10):776-85.

31. Keune K, Mass J, Mahta A, Church J, Meirer F. Analytical imaging studies of the migration of degraded orpiment, realgar, and emerald green pigments in historic paintings and related conservation issues. Herit Sci. 2016:4:10.

32. Keune K, Mass J, Meirer F, Pottasch C, Van Loon A, Hull A, Church J, Pouyet E, Cottegh M, Mehta A. Tracking the transformation and transport of arsenic sulfide pigments in paints: synchrotron-based X-ray micro-analyses. J Anal At Spectrom. 2015:30:813-27.

33. Buse J, Otero V, Melo M. New insights into synthetic copper greens: the search for specific signatures by Raman and Infrared spectroscopy for their characterization in medieval artworks. Heritage. 2019;2:1614-29.

34. Ma Q, Pan L. Translators. In: Scott D, editor. Copper and bronze in art: corrosion, colorants, conservation. Beijing: Science Press; 2009. p. 111.

35. Xia Y. Chinese historical pigments in polarized light microscope. Beijing: Science Press; 2017. p. 81-90.

36. Lei Y. Copper trihydroxychlorides as pigments in China. Stud Conserv. 2012;57(2):106-11.

37. Mazzeo R, Cam D, Chiavari G, Fabbri D, He L, Prati S. Analytical study of traditional decorative materials and techniques used in Ming Dynasty wooden architecture. The case of the Drum Tower in Xi an, P.R. of China. J Cult Herit. 2004;5(3):273-83.

38. Cardell-Fernández C, Navarrete-Aguilera C. Pigment and plasterwork analyses of Nasrid Polychromed Lacework Stucco in the Alhambra (Granada, Spain). Stud Conserv. 2006;51(3):161-76.

39. Plesters J. Ultramarine blue, natural and artificial. Stud Conserv. 1966;11(2):62-91.

40. Wang J. Study on synthetic Ultramarine blue in Dunhuang. Dunhuang Res. 2000;1:76-81.

41. Mi D. Investigation and research on statues of Pilu Nunnery of Shengshou Temple at Baoding Mountain in Dazu District of Chongqing. Sichuan Cult Rel. 2019;204(2):53-63.
42. Zheng L, Fu X. Study on mechanism of water condensation and field experiments of Thousand-Hand Guanyin in Dazu Rock Carvings. IOP Conf Ser: Earth Environ Sci. 2018;186(2):012007.

43. Kim MJ, Nriagu J. Oxidation of arsenite in groundwater using ozone and oxygen. Sci Total Environ. 2000;247(1):71-9.

44. Chakkaravarthy C, Waheed A, Udupa H. Zinc-air alkaline batteries-A review. J Power Sources. 1981;6(3):203-28.

45. Yao S, Jia Y, Zhao S. Photocatalytic oxidation and removal of arsenite by titanium dioxide supported on granular activated carbon. Environ Technol. 2012;33(9):983-8.

46. Ondruš P, Veselovský F, Hloušek J, SKála R, Vavěín I, Frýda J, Čejka J, Gabašová A. Secondary minerals of the Jáchymov (Joachimsthal) ore district Sekundární minerály jáchymovského rudního revíru (Czech summary). J Czech Geol Soc. 1997:42(2):3-69.

47. Kotulanová E, Bezdička P, Hradil D, Hradilová J, Švarcová S, Grygar T. Degradation of lead-based pigments by salt solutions. J Cult Herit. 2009;10:267-78.

48. Wang D, Zhang Z, Fu L, Yao J, Xie B, Yan X. Analyses of formation and chemical characteristics of weathering products on carved rockwall in Baodingshan Grotto. J Eng Geol. 1995;3(3):18-29.

49. Benner S, Devine K, Matveeva, Powell. The missing organic molecules on Mars. Proc Natl Acad Sci USA. 2000;97(6):2425-30.

50. Cariati F, Rampazzi L, Toniolo L, Pozzi A. Calcium oxalate films on stone surfaces: experimental assessment of the chemical formation. Stud Conserv. 2000:45:180-8.

51. Salvadó N, Butí S, Nicholson J, Emerich H, Labrador A, Pradell T. Identification of reaction compounds in micrometric layers from gothic paintings using combined SR-XRD and SR-FTIR. Talanta. 2009;79:419-28.

52. Otero V, Vilarigues M, Carlyle L, Cotte M, De NolfW, Melo M. A little key to oxalate formation in oil paints: protective patina or chemical reactor? Photochem Photobiol Sci. 2018;17:266-70.

\section{Publisher's Note}

Springer Nature remains neutral with regard to jurisdictional claims in published maps and institutional affiliations.

\section{Submit your manuscript to a SpringerOpen ${ }^{\circ}$ journal and benefit from:}

- Convenient online submission

- Rigorous peer review

- Open access: articles freely available online

- High visibility within the field

- Retaining the copyright to your article

Submit your next manuscript at springeropen.com 